CHILDREN OF THE ATOMIC BOMB 
Asia-Pacific: Culture, Politics, and Society

Editors: Rey Chow, H. D. Harootunian, and Masao Miyoshi 


\section{ChILDREN OF THE ATOMIC BOMB}

An American Physician's Memoir of Nagasaki,

Hiroshima, and the Marshall Islands

JAMES N. YAMAZAKI with Louis B. Fleming 
The costs of publication for this book have been supported in part by a 1994 Hiromi Arisawa Award, given to Duke University Press for publication of an outstanding work on Japan.

(C) 1995 Duke University Press All rights reserved

Printed in the United States of America on acid-free paper $\infty$ Typeset in Berthold Bodoni Antiqua by Tseng Information Systems, Inc. Library of Congress Cataloging-in-Publication Data appear on the last printed page of this book. 